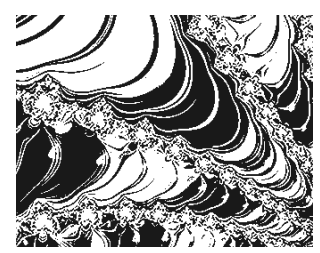

https://doi.org/10.5559/di.30.2.01

\title{
TRANSFORMATIONAL LEADERSHIP AND INSTRUCTIONAL QUALITY DURING THE COVID-19 PANDEMIC: A MODERATED MEDIATION ANALYSIS
}

Irena BURIĆ

Department of Psychology, University of Zadar, Zadar, Croatia Maja PARMAČ KOVAČIĆ, Aleksandra HUIĆ Faculty of Humanities and Social Sciences, University of Zagreb, Zagreb, Croatia

UDK: 159.913:37.091.321:[616.98:578.828COVID-19] $37.091 .321:[616.98: 578.828 C O V I D-19]: 004.77$

Izvorni znanstveni rad

Primlieno: 30. 9. 2020.

The school lockdown caused by the COVID-19 pandemic pushed teachers to online teaching literally overnight, which put their performance at risk. Transformational school leadership (TSL), teacher self-efficacy (TSE) and digital competencies might have played a protective role in such burdening conditions. Therefore, the present study aimed to examine the mediating role of TSE in explaining the relationship between TSL and instructional quality. Additionally, the moderating role of digital competencies in explaining the interrelations between TSL and TSE as well as between TSE and instructional quality, or the proposed mediating mechanism, was tested. The study was conducted via online survey in Spring 2020 and involved 1655 Croatian teachers. The mediation and moderated mediation analyses revealed that TSL was positively related to instructional quality both directly and indirectly via TSE. Teacher digital competencies did not moderate the proposed relationships or the mediating mechanism.

Keywords: transformational school leadership, teacher effectiveness, teacher self-efficacy, digital competencies, moderated mediation

Irena Burić, Department of Psychology, University of Zadar, Obala kralja Petra Krešimira IV. br. 2, 23000 Zadar, Croatia. E-mail: iburic@unizd.hr 
In March 2020, shortly after the World Health Organization characterized the COVID-19 outbreak as pandemic, Croatian schools were shut down and thousands of teachers and students were tossed into distant teaching and learning overnight. The majority of them had no prior experience in any kind of online schooling, which had put an enormous challenge in front of all the actors involved in education - students, their parents, school administration, and teachers. Such an abrupt and major change in the ways of delivering instruction could have threatened their professional well-being and their effectiveness. To preserve their job performance and to ensure high-quality instruction, teachers needed to rely on their own skills and confidence. In addition, school principals and their leadership style became even more important for optimal school functioning during these demanding and uncertain times.

In contemporary school settings, transformational school leadership (TSL) is the most appropriate leadership style since it promotes overall school performance (Anderson, 2017). TSL can foster teaching quality both directly and indirectly by building teacher self-efficacy (TSE), that is, a belief in capabilities to teach a subject matter and to engage all students in learning (Tschannen-Moran \& Woolfolk Hoy, 2001). Indeed, studies show that TSE is positively related to TSL (e.g., Gkolia et al., 2018; Li \& Liu, 2020) and to teacher effectiveness (Klassen \& Tze, 2014), therefore, suggesting that TSE could have a central role in explaining the relationship between TSL and instructional quality. In addition, since all teaching activities had to be transferred to online platforms, possessing a sufficient quantity of digital skills became another important factor that could have helped teachers to successfully adopt online teaching without experiencing a drop in performance.

The association between transformational leadership and job performance is an empirically established fact (e.g., Fuller et al., 1996; Judge \& Piccolo, 2004). However, the underlying mediational mechanism (i.e., how transformational leadership explains job performance) and moderating mechanism (i.e., when this mediating mechanism is the strongest) have been rarely explored among teachers and especially not in times of global crisis such as the COVID-19 pandemic. Therefore, the aim of the present research was to examine the role of TSE (as a possible mediator) and digital competencies (as a possible moderator) in explaining the relationship between TSL and teachers' instructional quality in virtual classrooms during the pandemic. Uncovering the underlying mechanisms that may explain the complex relationship between TSL and teachers' performance is an important and under-investigated topic even 
in regular circumstances but especially in times of a worldwide crisis caused by the pandemic that have reached all spheres of society, including education.

\section{Transformational School Leadership and Instructional Quality}

Teachers differ in their capabilities to produce a positive impact on students' learning and academic achievement, that is, they vary in their performance or effectiveness (Gordon et al., 2006). One of the most widely used models of effective teaching is the Three Basic Dimensions Framework (Praetorius et al., 2018), according to which key elements of high quality teaching are classroom management, cognitive activation, and supportive climate. Classroom management implies a well-structured learning environment with low level of interruptions and efficient use of time; cognitive activation refers to providing challenging tasks and activities that stimulate higher order thinking processes; and supportive climate implies a positive approach to students, constructive feedback and caring teacher behavior (Fauth et al., 2014; Praetorius et al., 2018).

The Three Basic Dimensions Framework (Praetorius et al., 2018) was developed to describe instructional quality in classical classrooms. However, all three dimensions of instructional quality can be adapted to virtual classrooms as well. For example, classroom management in virtual settings may imply teachers' skills to keep their students focused and devoted to the task by efficiently organizing their learning schedule and ensuring that students follow established virtual classroom rules. Cognitive activation can be accomplished by offering students cognitively challenging tasks or engaging them in stimulating online discussions, while virtual classroom support could be ensured by prompt responding to students' emails and questions and by helping them to overcome possible technical and organizational difficulties that may obstruct their learning progress.

TSL was recognized as the leadership style that enhances overall school organizational performance (Anderson, 2017). In general, "transformational leadership is the process by which a leader fosters group or organizational performance beyond expectation by virtue of the strong emotional attachment with his or her followers combined with the collective commitment to a higher moral cause" (Díaz-Sáenz, 2011, p. 299). Transformational leaders motivate followers not only to fulfil their expectations, but also to perform beyond what is expected from them by making them more aware of the importance of task outcomes and inducing them to transcend their own self-interest for the sake of the team or organization (Yukl, 2013). In addition, such leaders help followers to develop their own 
DRUŠ. ISTRAŽ. ZAGREB GOD. 30 (2021), BR. 2, STR. 181-202

BURIĆ I. ET AL: TRANSFORMATIONAL... leadership potential by empowering them and paying attention to their individual needs and personal development (Bass \& Riggio, 2006; Yukl, 2013). All these behaviors result in having followers that are more committed and satisfied than followers of any other type of leaders (Bass \& Riggio, 2006).

One of the most often-studied outcomes of transformational leadership is job performance. Research has unequivocally shown that transformational leadership behaviors are strongly and consistently associated to high employee performance (e.g., Fuller et al., 1996; Judge \& Piccolo, 2004). Transformational leaders provide constructive feedback to their employees, convince them to exhibit an extra effort, and encourage them to think creatively about complex problems. Because of these behaviors, employees tend to be more committed and to behave in ways that facilitate high levels of task performance (Piccolo \& Colquitt, 2006).

Previous studies showed that TSL is positively related to teacher commitment (e.g., Li \& Liu, 2020; Thomas et al., 2018), classroom practices (Leithwood \& Jantzi, 1999; Leithwood \& Mascall, 2008; Thoonen et al., 2011), and to students' academic success (Sun \& Leithwood, 2012). However, even though these findings suggest that TSL might be an important factor in shaping teacher effectiveness, research in this field is still scant. Specifically, to the best of our knowledge, empirical evidence on the relationship between TSL and the three dimensions of instructional quality is most likely nonexistent. Nonetheless, based on the abundance of research about positive effects of transformational leadership on job performance in the field of work and organizational psychology (e.g., Fuller et al., 1996; Judge \& Piccolo, 2004; Keller, 2006) or in the more general field of teacher effectiveness (e.g., Thoonen et al., 2011; Sun \& Leithwood, 2012), it can be expected that TSL would have beneficial effects on the three dimensions of instructional quality as well.

\section{The Mediating Role of Teacher Self-Efficacy}

One of the primary motivational mechanisms through which transformational leaders influence their followers is the enhancement of their self-efficacy (House \& Shamir, 1993). According to the social-cognitive theory (Bandura, 1997), self-efficacy beliefs are formed based on four groups of experiences: mastery experience or prior performance, vicarious experience or observing others performing successfully, verbal persuasion, and emotions or physiological experiences of stress and anxiety. It appears that transformational leadership behaviors parallel the main determinants of self-efficacy, such as role-modelling, verbal/social persuasion, and psychological arousal 
DRUŠ. ISTRAŽ. ZAGREB GOD. 30 (2021), BR. 2, STR. 181-202

BURIĆ, I. ET AL.: TRANSFORMATIONAL..
(Pillai \& Williams, 2004). For example, Podsakoff et al. (1990) suggested that transformational leaders influence followers by role-modelling the appropriate behaviors. Followers identify with role models who are then perceived in a positive light, and this serves to empower them to achieve the leader's vision through the development of self-efficacy (Kirkpatrick \& Locke, 1996; Yukl, 2013).

Numerous studies have confirmed the positive relationship between transformational leadership and self-efficacy among employees from various organizations (e.g., Caillier, 2014; Liu et al., 2010; Nielsen \& Munir 2009; Pillai \& Williams, 2004). Similar findings were found in the educational context as well - TSL was related to both individual TSE (Demir, 2008; Nir \& Kranot, 2006) and collective self-efficacy (Demir, 2008; Ninković \& Knežević Florić, 2018). Therefore, it can be expected that TSL will be positively related to TSE during the exceptional circumstances caused by the lockdown as well.

In turn, self-efficacy is considered as an important predictor of one's job performance. People with greater self-efficacy exhibit better job performance since they are more persistent, work harder, and are less prone to stress (e.g., Bandura, 1997; Judge et al., 2007). Similarly, teachers with higher TSE deliver instruction of greater quality, and have students who are more motivated and perform better (Klassen \& Tze, 2014; Midgley et al., 1989; Tschannen-Moran et al., 1998). Moreover, studies showed that TSE is positively related to efficient classroom management (Burić \& Kim, 2020; Guo et al., 2012), cognitive activation (e.g., Burić \& Kim, 2020; Schiefele $\&$ Schaffner, 2015), and providing supportive classroom environment (e.g., Burić \& Kim, 2020; Künsting et al., 2016). Considering both the conceptual and empirical salience of TSE in explaining teacher performance (see Zee \& Koomen, 2016 for review), we expected that TSE would be positively related to all three dimensions of instructional quality, that is, to classroom management, cognitive activation, and supportive climate. However, it should be noted that longitudinal empirical evidence revealed the reverse pattern in which instructional quality was an antecedent of TSE (Holzberger et al., 2013), indicating that TSE and instructional quality could be reciprocally related.

In sum, theoretical considerations and available research clearly indicate that in regular times, TSL could foster both TSE and instructional quality and that TSE is an important determinant of high instructional quality. Consequently, TSE could have a mediating role in explaining the relationship between TSL and the three dimensions of instructional quality. Indeed, empirical evidence supports the mediating role of 
DRUŠ. ISTRAŽ. ZAGREB GOD. 30 (2021), BR. 2, STR. 181-202

BURIĆ I. ET AL: TRANSFORMATIONAL... self-efficacy in explaining the relationship between transformational leadership and job performance (e.g., Gong et al., 2009; Salanova et al., 2011). It should be noted that the positive direct effects of TSL on instructional quality and indirect effects of TSL on instructional quality through TSE could have been even more pronounced in the context of the abrupt and major shift in ways of delivering instruction due to the pandemic.

\section{Teacher Digital Competencies}

Switching to distance teaching and learning caused by the COVID-19 pandemic meant teachers had to massively start to rely on information and communications technologies (ICT) to achieve learning outcomes. In order to successfully integrate ICT into teaching, to involve students in active online learning and to manage their online classrooms successfully, they needed to be competent in the use of ICT. Prior to the lockdown, Croatian teachers mostly used ICT tools for administrative tasks and lesson preparation, and only rarely for online teaching (Mohorić et al., 2020). In addition, the level of their digital competencies was mostly low to average (Pahljina-Reinić et al., 2020). Even in regular circumstances, when making the transition from face-to-face to online teaching, teachers tend to report high levels of frustration and doubt but recognize the importance of being digitally competent for successful teaching (Tschida et al., 2016).

Teachers' digital competencies might have been crucial for maintaining satisfactory levels of instructional quality during the lockdown. For example, previous research showed that mastery over ICT tools and knowledge about integrating these tools into teaching contribute to higher ICT use in classrooms (European Commission, 2013, 2019; Voogt et al., 2013). Moreover, teachers' digital skills were found to be related to higher levels of TSE (Elstad \& Christophersen, 2017), which is particularly important in the working conditions characterized by high levels of stress and uncertainty related to the pandemic. Indeed, available data suggests that teachers' digital competencies seemed to be instrumental in successful adaptation to remote teaching during the COVID-19 pandemic (König et al., 2020). Therefore, we expected that teachers with more developed digital competencies would show better adjustment in the online teaching context, that is, their digital competencies would be related to greater TSE and instructional quality.

Moreover, the level of their digital competencies could change the strength of the proposed relationships between TSL, TSE, and instructional quality. More specifically, for teachers 
DRUŠ, ISTRAŽ. ZAGREB GOD. 30 (2021), BR. 2, STR. 181-202

BURIĆ, I. ET AL.: TRANSFORMATIONAL.. with low levels of digital competencies, having school principals who are better transformational leaders might be more important in preserving their TSE or instructional quality since they would need greater support and stronger guidance. In contrast, the positive effects of TSL on instructional quality via TSE might be less pronounced among teachers with great digital skills and knowledge, considering that those teachers are already competent and capable enough to successfully deal with challenges brought on by switching to online teaching.

\section{The Present Study}

The major lockdown caused by the COVID-19 pandemic posed a unique challenge for teachers. They had to switch to online teaching literally overnight without prior preparation that would preserve their performance in, for most of them, completely novel virtual settings. Such circumstances not only put teachers' professional well-being at stake, but also jeopardized their effectiveness. Having school principals who are transformational leaders or having high levels of self-efficacy and digital competencies might have played a protective role in such burdening conditions. Moreover, despite their relevance for teacher professional development and quality of education in general, TSL, TSE, digital competencies, and instructional quality have rarely been investigated jointly. This claim especially holds in relation to the extraordinary and unique circumstances caused by the major lockdown due to the COVID-19 pandemic. Therefore, the present study aimed at examining the mediating role of TSE in explaining the relationship between TSL and three dimensions of instructional quality. Additionally, the possible moderating role of digital competencies that could have changed the strength of the interrelations between TSL and TSE as well as between TSE and instructional quality, or the strength of the proposed mediating mechanism, was tested. This conceptual model is depicted in Figure 1.

Based on the theoretical considerations and past research outlined in previous sections, we postulated the following hypotheses:

Hypothesis 1. TSE will partially mediate the relationship between TSL and instructional quality. More specifically, TSL will be positively related to TSE, which will in turn be positively related to instructional quality. In addition, TSL will be positively and directly related to instructional quality.

Hypothesis 2. Teacher digital competencies will moderate between TSL and instructional quality. In particular, a posi- 
DRUŠ. ISTRAŽ. ZAGREB GOD. 30 (2021), BR. 2, STR. 181-202

BURIĆ, I. ET AL.: TRANSFORMATIONAL..
P FIGURE 1 Hypothesized moderated mediation model tive association between TSL and TSE, as well as the association between TSL and instructional quality will be stronger among teachers with lower levels of digital competencies when compared to teachers with moderate or high levels of digital competencies.

Hypothesis 3. Teacher digital competencies will moderate the mediating effect of TSE in the relationship between TSL and instructional quality. Namely, the positive effects of TSL on instructional quality via TSE will be less strong among teachers with higher levels of digital competencies.

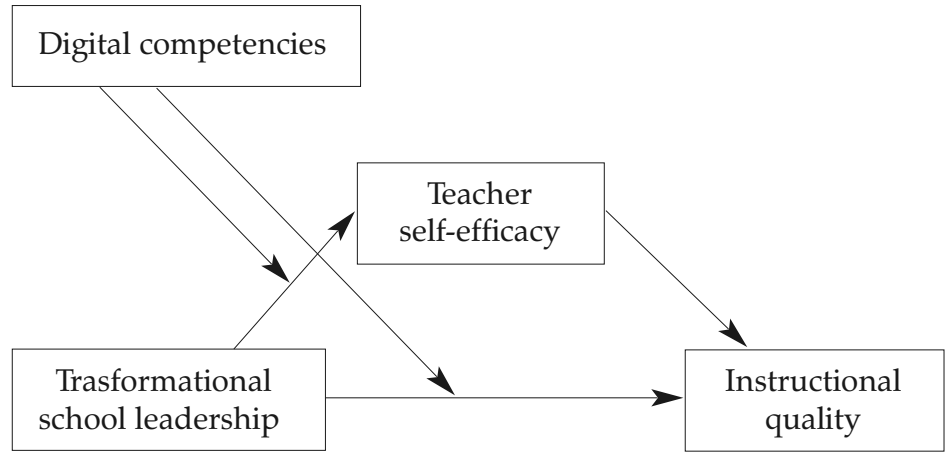

\section{METHOD}

\section{Participants and Procedure}

A total of 1655 teachers ( $84 \%$ women) participated in the study in Spring 2020, during the lockdown caused by the COVID-19 pandemic. Because of the lockdown, all teaching and learning activities were shifted to different online platforms (e.g., Google Classroom, MS Teams). Teachers were between 23 and 70 years old $(M=42.93$; $S D=9.93)$, and their teaching experience ranged from less than 6 months to 43 years $(M=15.70$; $S D=10.30$ ). They came from 227 Croatian schools (out of 640 schools that were contacted by the research team), taught a wide range of subjects (e.g., Croatian language, foreign language, mathematics, physics, chemistry, biology, ICT, history, geography) at three educational levels - elementary school level $(N=433 ; 26 \%)$, middle school level $(N=729 ; 44 \%)$ and high school level $(N=493 ; 30 \%)$.

Data were collected online via survey in Google Forms. Invitations for participation in the study, as well as the link to the survey, were sent to school principals via email. Those school principals, who agreed for their teachers to participate in the study, forwarded the link to teachers in their school. Teacher participation was anonymous and voluntary, and 
teachers gave their informed consent to participate in the study. The Institutional Ethics Review Board of the first author approved the study.

\section{Instruments}

The Global Transformational Leadership Scale (Carless et al., 2000) was used to examine teachers' assessment of their principal's behaviors such as communicating vision, developing staff, providing support, empowering staff, innovation, leading by example, and charisma. Teachers evaluated their school principals' behaviors described in 7 items using a scale ranging from 1 (never) to 5 (very often, almost always). A sample item is: "My school principal treats staff as individuals, supports and encourages their development."

Teacher Efficacy Scale (TSE; Schwarzer et al., 1999) measures perceptions of self-efficacy in different areas of working as a teacher, like job accomplishment, skill development, interactions with students, and coping with job stress. Teachers were asked to rate their agreement with each of the 10 items on a 4-point scale ranging from 1 (not at all true) to 4 (exactly true). A sample item is: "I am convinced that I am able to successfully teach all relevant subject content to even the most difficult students."

Instructional quality was measured by adapted scales taken from Burić \& Kim (2020). These scales assess three dimensions of instructional quality - classroom management (4 items; e.g. "I make sure students pay attention"), cognitive activation (8 items, e.g., "I try to give tasks and ask questions that make students think"), and supportive classroom (4 items, e.g. "I am aware of student's feelings"). Teachers self-assessed their teaching behaviors by rating their agreement on a 5-point scale (1 do not agree at all; 5 - completely agree).

Teacher Digital Competencies were measured by 10 items especially designed for this study. The scale was based on the DigiCompEdu framework (Redecker, 2017) and the Teacher Digital Competencies Scales (Pahljina-Reinić et al., 2020). The items describe ICT skills and their integration into teaching (e.g., "I am skilled in using online learning platforms (Moodle, MS Teams, Zoom etc.)"). Teachers rated their agreement with each item on a scale ranging from 1 (do not agree at all) to 7 (agree completely). Since this was a newly created scale that was administered for the first time in this study, its latent structure was examined by exploratory factor analysis with maximum likelihood estimation method. One factor was extracted with initial eigenvalue $\lambda=6.063$ that accounted for $60.63 \%$ of variability.

All scales had satisfactory to high levels of internal consistency (see Table 1). While teachers rated their digital com- 
DRUŠ. ISTRAŽ. ZAGREB

GOD. 30 (2021), BR. 2,

STR. 181-202

BURIĆ, I. ET AL.:

TRANSFORMATIONAL... petencies and transformational leadership of their school principals in general, TSE and dimensions of instructional quality were assessed in reference to the school lockdown caused by the pandemic (i.e., teachers rated their self-efficacy and instructional quality in the context of online teaching).

\section{Analytical Strategy}

First, descriptive statistics, correlations among examined variables, and intraclass correlations (ICC1) of dependent variables (i.e., the proportion of the total variance occurring at the school level) were calculated. Second, in order to test the study hypotheses, several path models were specified and tested. Mediation analysis examines how the independent variable affects the dependent variable, while moderation analysis reveals when the independent variable affects the dependent variable (Hayes, 2013). In the present research, we tested the mediating role of TSE in explaining the relationship between TSL and instructional quality (Hypothesis 1). Next, we tested the moderating role of teacher digital competencies in explaining the relationships between TSL and TSE, as well as between TSL and instructional quality (Hypothesis 2). Finally, we tested the moderated mediation effects, that is, the assumption according to which the mediation process depends on a value of the moderated variable (Edwards \& Lambert, 2007; Hayes, 2013). If the mediating role of TSE in explaining the relationship between TSL and instructional quality varied across different values of the teacher digital competencies, moderated mediation would be established (Hypothesis 3).

In order to test our mediation hypothesis (Hypothesis 1), we specified and tested a single path model. However, to test the moderation and moderated mediation hypotheses (i.e., Hypothesis 2 and Hypothesis 3) we tested three separate models. In each of the models, one out of three dimensions of instructional quality (i.e., classroom management, cognitive activation, and supportive climate) served as the dependent variable. All analyses were conducted in Mplus 8.4 (Muthén \& Muthén, 1998-2017) with maximum likelihood estimator (ML). The bootstrap method $(n=10000)$ was implemented to determine statistical significance (i.e., confidence intervals) of the mediating effects. All constructs in the models were introduced as manifest variables which made the models just-identified (i.e., the number of degrees of freedom equals the number of parameters that are estimated in the model). Therefore, the validity of the study hypotheses was evaluated based on the size and statistical significance of the specified and tested paths in the models.

All the models were based on manifest variables, which is considered as an approach that is both convenient and easy 
DRUŠ. ISTRAŽ. ZAGREB GOD. 30 (2021), BR. 2, STR. 181-202

BURIĆ, I. ET AL.: TRANSFORMATIONAL.. to grasp (Cheung \& Lau, 2017). In addition, testing complex moderated mediation models based on latent variables (i.e., the latent moderated structural equations (LMS) approach) still has rather limited usage in applied research due to current software limitations (e.g., inability to calculate model fit indices that can be used to evaluate overall model fit; Feng et al., 2020).

\section{RESULTS}

\section{Descriptive Statistics and Correlational Analysis}

Prior to testing the hypothesized relationships among study constructs, the amount of variability that may occur at the school level due to hierarchical structure of the data (i.e., teachers were nested in schools) was determined. All intraclass correlations (ICC1) for dependent variables were less than 0.05, indicating no need for conducting multilevel analysis (Lüdtke et al., 2011). The results of preliminary correlational analyses are shown in Table 1. Female teachers reported somewhat higher levels of TSE and instructional quality. Teachers with more years of teaching experience rated their school principals as less transformational and reported lower levels of digital competencies and poorer classroom management skills. Higher ratings of transformational leadership of school principals were related to higher levels of TSE, teacher digital competencies and instructional quality. In addition, higher levels of TSE were related to higher levels of digital competencies

(1) TABLE 1

Descriptive statistics and correlations and instructional quality. Lastly, the correlations between the three dimensions of instructional quality were all high and positive.

\begin{tabular}{lcccccccc}
\hline & 1 & 2 & 3 & 4 & 5 & 6 & 7 & 8 \\
\hline 1 Gender ${ }^{1}$ & - & & & & & & & \\
2 Years of teaching experience & 0.09 & - & & & & & & \\
3 TSL & -0.04 & -0.14 & - & & & & & \\
4 TSE & 0.10 & -0.02 & 0.19 & - & & & & \\
5 Digital competencies & 0.03 & -0.31 & 0.10 & 0.31 & - & & & \\
6 Classroom management & 0.14 & -0.08 & 0.19 & 0.53 & 0.29 & - & & \\
7 Cognitive activation & 0.15 & -0.03 & 0.17 & 0.54 & 0.26 & 0.76 & - & \\
8 Supportive climate & 0.21 & -0.01 & 0.20 & 0.54 & 0.23 & 0.73 & 0.79 & - \\
M & - & 15.70 & 4.25 & 4.16 & 4.94 & 4.34 & 2.68 & 4.49 \\
SD & - & 10.30 & 0.85 & 0.52 & 1.32 & 0.52 & 0.30 & 0.54 \\
Range & - & $0.5-43$ & $1-5$ & $1-5$ & $1-7$ & $1-5$ & $1-5$ & $1-5$ \\
Cronbach $\alpha$ & - & - & 0.96 & 0.89 & 0.92 & 0.74 & 0.90 & 0.86 \\
\hline
\end{tabular}

Notes. ${ }^{1}$ Dummy variable $(0=$ men, $1=$ females $)$;SL $=$ transformational school leadership, TSE $=$ teacher self-efficacy

The statistically non-significant correlations are shown in italics. All other values are statistically significant at $p<0.01$. 


\section{Testing the Mediation and Moderated Mediation Models}

The results of the tested mediation model are presented in Table 2. TSL was positively related to TSE. In turn, TSE had positive associations with classroom management, cognitive activation, and supportive climate. Moreover, TSL was positively related to all three dimensions of instructional quality - classroom management, cognitive activation, and supportive climate. In the next step, we calculated unstandardized indirect effects and their bias corrected confidence intervals. Indirect effects of TSL via TSE on classroom management, cognitive activation, and supportive climate were statistically significant $(b=0.032,99 \%$ C.I. [0.021, 0.046]; $b=0.05199 \%$ C.I. $[0.032,0.072] ; b=0.041,99 \%$ C.I. [0.025, 0.0460]; respectively). In sum, Hypothesis 1 was fully confirmed - TSE partially mediates the relationship between TSL and three dimensions of instructional quality. In other words, TSL contributes directly to all three dimensions of instructional quality, but also indirectly through TSE.

TABLE 2

Mediation model results
1 In moderated mediation analysis, variables of TSL and digital competencies were centered to grandmean.

\begin{tabular}{lrc}
\hline Effect & $\beta$ & S.E. \\
\hline TSL $\rightarrow$ TSE & 0.189 & 0.026 \\
TSE $\rightarrow$ classroom management & 0.481 & 0.029 \\
TSE $\rightarrow$ cognitive activation & 0.532 & 0.029 \\
TSE $\rightarrow$ supportive climate & 0.454 & 0.055 \\
TSL $\rightarrow$ classroom management & 0.094 & 0.022 \\
$\mathrm{TSL} \rightarrow$ cognitive activation & 0.072 & 0.021 \\
$\mathrm{TSL} \rightarrow$ supportive climate & 0.104 & 0.021 \\
$\mathrm{TSL} \rightarrow$ TSE $\rightarrow$ classroom management & 0.091 & 0.013 \\
$\mathrm{TSL} \rightarrow$ TSE $\rightarrow$ cognitive activation & 0.101 & 0.015 \\
$\mathrm{TSL} \rightarrow$ TSE $\rightarrow$ supportive climate & 0.086 & 0.016 \\
\hline
\end{tabular}

Note. All regression weights are statistically significant at $p<0.001$.

The results of the three tested moderated mediation models are presented in Table 3. Teacher digital competencies did not moderate the relationship between TSL and TSE or the relationships of TSL with classroom management, cognitive activation, and supportive climate. Therefore, Hypothesis 2 should be rejected. However, teacher digital competencies exhibited a positive relationship with TSE, classroom management, and cognitive activation, but not with supportive climate.

Lastly, as can be seen from the results of conditional direct effects and conditional indirect effects analyses (based on low moderator value at $-1 S D[-13.23],{ }^{1}$ medium moderator value at mean [0.00], and high moderator value at $+1 S D$ [13.23]) presented in Table 4, teacher digital competencies did not moderate any of the three mediating mechanisms. All three mediating effects (for three dimensions of instructional quality) were statistically significant and similar in size across all three 
DRUŠ. ISTRAŽ. ZAGREB GOD. 30 (2021), BR. 2, STR. 181-202

BURIĆ, I. ET AL.: TRANSFORMATIONAL..

(1) TABLE 3

Moderated mediation models results moderator values (i.e., low, medium, and high). The same conclusion applies to the direct effects with one exception - the direct effect of TSL on cognitive activation was nonsignificant at low level of teacher digital competencies $(b=0.020,95 \%$ C.I. $[-0.12,0.052])$. In contrast, this effect was statistically significant at both the medium $(b=0.035,95 \%$ C.I. $[0.014,0.056])$ and high levels $(b=0.050,95 \%$ C.I. [0.024, 0.077$])$ of teacher digital competencies. Overall, Hypothesis 3 should be rejected.

\begin{tabular}{|c|c|c|c|c|c|c|}
\hline & \multicolumn{2}{|c|}{$\begin{array}{l}\text { Classroom } \\
\text { management }\end{array}$} & \multicolumn{2}{|c|}{$\begin{array}{l}\text { Cognitive } \\
\text { activation }\end{array}$} & \multicolumn{2}{|c|}{$\begin{array}{l}\text { Supportive } \\
\text { climate }\end{array}$} \\
\hline & $\beta$ & S.E. & $\beta$ & S.E. & $\beta$ & S.E. \\
\hline TSE $\rightarrow$ Instructional quality dimension & $0.445^{* *}$ & 0.029 & $0.498^{* *}$ & 0.030 & $0.448^{* *}$ & 0.049 \\
\hline TSL $\rightarrow$ Instructional quality dimension & $0.090^{* *}$ & 0.021 & $0.069^{* *}$ & 0.021 & $0.103^{* *}$ & 0.021 \\
\hline $\begin{array}{l}\text { Digital competencies } \rightarrow \text { Instructional } \\
\text { quality dimension }\end{array}$ & $0.112^{* *}$ & 0.027 & $0.109^{* *}$ & 0.023 & 0.021 & 0.033 \\
\hline $\begin{array}{l}\text { TSL } x \text { Digital competencies } \rightarrow \text { Instructional } \\
\text { quality dimension }\end{array}$ & 0.002 & 0.021 & -0.030 & 0.021 & 0.013 & 0.020 \\
\hline $\mathrm{TSL} \rightarrow \mathrm{TSE}$ & $0.159^{* *}$ & 0.025 & $0.159^{* *}$ & 0.025 & $0.159^{* *}$ & 0.025 \\
\hline Digital competencies $\rightarrow$ TSE & $0.310^{* *}$ & 0.024 & $0.310^{* *}$ & 0.024 & $0.310^{* *}$ & 0.024 \\
\hline TSL $x$ Digital competencies $\rightarrow$ TSE & -0.006 & 0.026 & -0.006 & 0.026 & -0.006 & 0.026 \\
\hline$R^{2}$ & $0.268^{*}$ & 0.031 & $0.315^{* *}$ & 0.032 & $0.236^{* *}$ & 0.052 \\
\hline
\end{tabular}

Note. ${ }^{*} p<0.05,{ }^{* *} p<0.01$

$\begin{array}{lll}\begin{array}{l}\text { Classroom } \\ \text { management }\end{array} & \begin{array}{l}\text { Cognitive } \\ \text { activation }\end{array} & \frac{\begin{array}{l}\text { Supportive } \\ \text { c }[95 \% \text { C.I. }[95 \text { C.I. }]\end{array}}{\frac{b}{b}[95 \% \text { C.I. }]}\end{array}$

Conditional indirect effects

$\begin{array}{llll}M-1 S D(-13.23) & 0.026[0.014,0.039] & 0.042[0.023,0.061] & 0.035[0.019,0.053] \\ M(0.00) & 0.025[0.017,0.034] & 0.040[0.028,0.054] & 0.034[0.023,0.047] \\ M+1 S D(13.23) & 0.024[0.013,0.036] & 0.038[0.022,0.057] & 0.033[0.018,0.049] \\ \text { Conditional direct effects } & & & \\ M-1 S D(-13.23) & 0.031[0.009,0.055] & 0.020[-0.012,0.052] & 0.043[0.013,0.072] \\ M(0.00) & 0.032[0.018,0.047] & 0.035[0.014,0.056] & 0.049[0.028,0.070] \\ M+1 S D(13.23) & 0.033[0.015,0.051] & 0.050[0.024,0.077] & 0.055[0.031,0.082]\end{array}$

(1) TABLE 4

Conditional indirect and direct effects
Note. Bootstrap sample size was $n=10000$. Nonsignificant effect is shown in italics.

\section{DISCUSSION}

The aim of the present study was to test the mediating role of TSE in explaining the relationship between TSL and instructional quality during the lockdown caused by the COVID-19 pandemic and massive shift to distant teaching and learning. Considering the importance of having good digital skills in 
DRUŠ. ISTRAŽ. ZAGREB GOD. 30 (2021), BR. 2, STR. 181-202

BURIĆ, I. ET AL.: TRANSFORMATIONAL... such teaching conditions, the moderating role of teacher digital competencies in explaining the proposed mediating mechanisms was additionally examined.

In support of our first hypothesis, mediation analysis showed that TSE partially mediated the relationship between TSL and all three dimensions of instructional quality. As expected, having school principals who exhibited transformational leadership characteristics was positively associated with greater TSE. Principals who are good transformational leaders can serve as appropriate role models, can verbally persuade teachers that they can perform well and be successful even in completely novel settings, but can also help them to keep their stress levels low. Considering that all these behaviors present sources of self-efficacy, the positive link between TSL and TSE is in line with both theoretical considerations (Bandura, 1997; Pillai \& Williams, 2004) and previous empirical findings (e.g., Demir, 2008; Yukl, 2013).

In turn, TSE is associated with more efficient classroom management, higher levels of cognitive activation, and with provision of greater learning support to students. According to the social-cognitive theory (Bandura, 1997), individuals with higher self-efficacy perform better since they generally tend to work harder, are persistent, and experience lower levels of stress. Such features might be especially important with respect to teaching in extraordinary circumstances such as those caused by the lockdown, which resulted in rather strong relationships between TSE and all three dimensions of instructional quality. These results are supported by previous research (e.g., Burić \& Kim, 2020; Guo et al., 2012; Künstig et al., 2016).

Lastly, TSL was directly and positively (albeit rather weakly) related to instructional quality. School principals who are transformational leaders promote cooperation among teachers to reach a common goal, provide individual support and concern for their personal feelings and needs, challenge them to re-examine some of the assumptions about their instruction and ways it can be delivered, and hold high expectations regarding their performance (Valentine \& Prater, 2011). As a result, instructional quality can be preserved to some extent even during times of crisis. Indeed, in support of our findings, the positive effects of transformational leadership on employees' performance are established across occupations (e.g., Fuller et al., 1996; Judge \& Piccolo, 2004), but also in the field of teacher effectiveness (Sun \& Leithwood, 2012; Thoonen et al., 2011).

Our second and third hypotheses according to which teacher digital competencies would moderate the relation- 
DRUŠ, ISTRAŽ. ZAGREB GOD. 30 (2021), BR. 2, STR. 181-202

BURIĆ, I. ET AL.: TRANSFORMATIONAL.. ship between TSL and TSE, and TSL and instructional quality, as well as the underlying mediating mechanism, were not supported. The relationship between TSL and TSE, and the one between TSL and instructional quality did not differ depending on the level of teachers' digital competencies. It seems that TSL exhibits similar positive effects on both TSE and instructional quality regardless of teachers' digital skills and knowledge, which highlights the fact that transformational leadership characteristics of school principals are most likely universally important across different conditions and circumstances. Notwithstanding, conditional direct effects analysis showed that the size of the relationship between TSL and cognitive activation might to some extent depend on the level of digital competencies - this relationship was stronger for highly digitally skilled teachers than for those with average digital competencies, while it was near zero among teachers with low levels of digital literacy.

A similar conclusion could be reached concerning the size of the established mediating mechanism in the conditional analysis - TSE partially mediated the relationship between TSL and instructional quality and this effect did not substantially change depending on the conditions of low, medium, and high levels of teacher digital competencies. However, teacher digital competencies proved to be important in explaining both TSE and instructional quality. Teachers who rated their digital competencies as high also had higher levels of TSE in the context of online teaching. In addition, teachers with higher digital skills were able to manage the virtual classroom better as well as to provide their students with more cognitively challenging tasks. Having good skills in using online learning platforms, tools for virtual communication, or creating multimedia digital learning content was of crucial importance in the virtual teaching environment in an attempt to reach the desired learning outcomes. These findings are in line with the previous scarce knowledge in the field that confirmed the importance of teacher digital literacy in shaping both their confidence and performance (e.g., Elstad \& Christophersen, 2017; König et al., 2020).

In sum, failure to confirm the proposed hypotheses regarding the moderated role of teacher digital competencies points to two conclusions. First, good leadership skills of school principals could be essential for maintaining both TSE and instructional quality in times of the COVID-19 crisis regardless of the actual teachers' preparedness for tackling the challenges associated with remote teaching. In other words, perceiving school leaders as supportive, caring, and competent seems to help teachers in preserving their confidence and performance 
DRUŠ. ISTRAŽ. ZAGREB GOD. 30 (2021), BR. 2, STR. 181-202

BURIĆ I. ET AL: TRANSFORMATIONAL... in uncertain times. Second, having sufficient levels of digital literacy independently promotes successful teachers' adaptation to the online teaching environment.

For more complete understanding of our results, one should bear in mind some study limitations. First, the study was based on a cross-sectional design and any claim regarding causal or temporal ordering between constructs should be avoided. Relatedly, the established mediating mechanism should be considered with caution since the test of the concurrent mediation can yield ambiguous results; instead, longitudinal design should be implemented in order to prove true mediation (Jose, 2016). Next, all measures used in this study were based on self-reports, which may cause the common-method bias and lead to inflation in sizes of the established effects (Podsakoff et al., 2003). Furthermore, we used a convenience sample of teachers from schools whose principals agreed to participate. Based on the rather high average ratings of TSL and some dimensions of instructional quality (see Table 1), we can assume that teachers who enrolled in this study were most likely those who were well adjusted to their school environment. Finally, even though participation in this study was anonymous and teachers were asked to provide their honest responses, socially desirable responding and using self-serving strategies cannot be completely discarded. This is especially true when assessing instructional quality, which might have resulted in obtaining somewhat biased reports. Therefore, future studies should aim to replicate our findings by using longitudinal methods and reports from multiple sources.

Nonetheless, the present study has several strengths. First, it included a rather large sample of teachers employed at different educational levels. Second, most of the analyzed relationships have been rarely investigated in previous research, which is even more true with respect to the global crisis caused by the COVID-19 pandemic or online teaching in general. Third, the present research has important practical implications. Since TSL is positively related to teachers' instructional quality, schools should concentrate on developing their principals' transformational leadership skills (e.g., effective communication and listening skills, motivating and inspiring subordinates) or even selecting candidates that already possess these skills. Also, a positive relation of TSE with instructional quality emphasizes the importance of building teachers' self-efficacy, which can be accomplished either through effective leadership or by providing teachers with opportunities for mastery experiences, observing competent colleagues, keeping their stress levels at low intensity, etc. (Bandura, 1997). Our study suggests that such endeavors might be important at this time of pandemic, but in general as well. 
Anderson, M. (2017). Transformational leadership in education: A review of existing literature. International Social Science Review, 93(1), 4. https://doi.org/10.1002/jls.21423

Bandura, A. (1977). Self-efficacy: Toward a unifying theory of behavioral change. Psychological Review, 84(2), 191-215. https://doi.org/10. 1037/0033-295X.84.2.191

Bass, B. M., \& Riggio, R. E. (2006). Transformational leadership. Psychology Press. https://doi.org/10.4324/9781410617095

Burić, I., \& Kim, L. E. (2020). Teacher self-efficacy, instructional quality, and student motivational beliefs: An analysis using multilevel structural equation modeling. Learning and Instruction, 66, 101302. https://doi.org/10.1016/j.learninstruc.2019.101302

Caillier, J. G. (2014). Toward a better understanding of the relationship between transformational leadership, public service motivation, mission valence, and employee performance: A preliminary study. Public Personnel Management, 43(2), 218-239. https://doi.org/10.1177/0091026 014528478

Carless, S. A., Wearing, A. J., \& Mann, L. (2000). A short measure of transformational leadership. Journal of Business and Psychology, 14(3), 389-405. https://doi.org/10.1023/A:1022991115523

Cheung, G. W., \& Lau, R. S. (2017). Accuracy of parameter estimates and confidence intervals in moderated mediation models: A comparison of regression and latent moderated structural equations. Organizational Research Methods, 20(4), 746-769. https://doi.org/10. $1177 / 1094428115595869$

Demir, K. (2008). Transformational leadership and collective efficacy: The moderating roles of collaborative culture and teachers' self-efficacy. Eurasian Journal of Educational Research (EJER), (33), 93-112.

Díaz-Sáenz, H. R. (2011). Transformational leadership. In A. Bryman, D. Collinson, K. Grint, B. Jackson, \& M. Uhl-Bien (Eds.), The SAGE Handbook of leadership (pp. 299-310). Sage, Thousand Oaks.

Edwards, J. R., \& Lambert, L. S. (2007). Methods for integrating moderation and mediation: A general analytical framework using moderated path analysis. Psychological Methods, 12(1), 1-22. https://doi.org/ 10.1037/1082-989x.12.1.1

Elstad, E., \& Christophersen, K. A. (2017). Perceptions of digital competency among student teachers: Contributing to the development of student teachers' instructional self-efficacy in technology-rich classrooms. Education Sciences, 7(1), 27. https://doi.org/10.3390/educsci7010027

European Commission (2013). Survey of schools: ICT in education. Publications Office of the European Union. https:/ec.europa.eu/digitalsingle-market/en/news/survey-schools-ict-education

European Commission (2019). 2nd Survey of schools: ICT in education. Objective 1: Benchmark progress in ICT in schools FINAL REPORT. Publications Office of the European Union. https://ec.europa.eu/digital-singlemarket/en/news/2nd 
DRUŠ. ISTRAŽ. ZAGREB GOD. 30 (2021), BR. 2, STR. 181-202

BURIĆ I. ET AL: TRANSFORMATIONAL...
Fauth, B., Decristan, J., Rieser, S., Klieme, E., \& Büttner, G. (2014). Student ratings of teaching quality in primary school: Dimensions and prediction of student outcomes. Learning and Instruction, 29, 1-9. https://doi.org/10.1016/j.learninstruc.2013.07.001

Feng, Q., Song, Q., Zhang, L., Zheng, S., \& Pan, J. (2020). Integration of moderation and mediation in a latent variable framework: A comparison of estimation approaches for the second-stage moderated mediation model. Frontiers in Psychology, 11, 2167. https://doi.org/10. 3389/fpsyg.2020.02167

Fuller, J. B., Patterson, C. E., Hester, K. I. M., \& Stringer, D. Y. (1996). A quantitative review of research on charismatic leadership. Psychological Reports, 78(1), 271-287. https://doi.org/10.2466/pr0.1996.78.1.271

Gkolia, A., Koustelios, A., \& Belias, D. (2018). Exploring the association between transformational leadership and teacher's self-efficacy in Greek education system: A multilevel SEM model. International Journal of Leadership in Education, 21(2), 176-196. https://doi.org/10. 1080/13603124.2015.1094143

Gong, Y., Huang, J. C., \& Farh, J. L. (2009). Employee learning orientation, transformational leadership, and employee creativity: The mediating role of employee creative self-efficacy. Academy of $\mathrm{Ma}$ nagement Journal, 52(4), 765-778. https://doi.org/10.5465/amj.2009. 43670890

Gordon, R. J., Kane, T. J., \& Staiger, D. (2006). Identifying effective teachers using performance on the job (No. 2006-01). Brookings Institution.

Guo, Y., Connor, C. M., Yang, Y., Roehrig, A. D., \& Morrison, F. J. (2012). The effects of teacher qualification, teacher self-efficacy, and classroom practices on fifth graders' literacy outcomes. The Elementary School Journal, 113(1), 3-24. https://doi.org/10.1086/665816

Hayes, A. F. (2013). Methodology in the social sciences. Introduction to mediation, moderation, and conditional process analysis: A regression-based approach. Guilford Press.

Holzberger, D., Philipp, A., \& Kunter, M. (2013). How teachers' self-efficacy is related to instructional quality: A longitudinal analysis. Journal of Educational Psychology, 105(3), 774-786. https://doi.org/10.1037/a0032198

House, R. J., \& Shamir, B. (1993). Toward the integration of transformational, charismatic, and visionary theories. In M. M. Chemers \& R. Ayman (Eds.), Leadership theory and research: Perspectives and directions (pp. 81-107). Academic Press.

Jose, P. E. (2016). The merits of using longitudinal mediation. Educational Psychologist, 51(3-4), 331-341. https://doi.org/10.1080/00461520. 2016.1207175

Judge, T. A., \& Piccolo, R. F. (2004). Transformational and transactional leadership: A meta-analytic test of their relative validity. Journal of Applied Psychology, 89(5), 755-768. https://doi.org/10.1037/0021-9010. 89.5.755

Judge, T. A., Jackson, C. L., Shaw, J. C., Scott, B. A., \& Rich, B. L. (2007). Self-efficacy and work-related performance: The integral role of individual differences. Journal of Applied Psychology, 92(1), 107-127. https://doi.org/10.1037/0021-9010.92.1.107 
DRUŠ. ISTRAŽ. ZAGREB GOD. 30 (2021), BR. 2, STR. 181-202

BURIĆ, I. ET AL.: TRANSFORMATIONAL..
Keller, R. T. (2006). Transformational leadership, initiating structure, and substitutes for leadership: A longitudinal study of research and development project team performance. Journal of Applied Psychology, 91(1), 202-210.

Kirkpatrick, S. A., \& Locke, E. A. (1996). Direct and indirect effects of three core charismatic leadership components on performance and attitudes. Journal of Applied Psychology, 81(1), 36-51. https://doi.org/10. 1037/0021-9010.81.1.36

Klassen, R. M., \& Tze, V. M. (2014). Teachers' self-efficacy, personality, and teaching effectiveness: A meta-analysis. Educational Research Review, 12, 59-76. https://doi.org/10.1016/j.edurev.2014.06.001

König, J., Jäger-Biela, D. J., \& Glutsch, N. (2020). Adapting to online teaching during COVID-19 school closure: Teacher education and teacher competence effects among early career teachers in Germany. European Journal of Teacher Education, 43(4), 608-622. https://doi.org/ 10.1080/02619768.2020.1809650

Künsting, J., Neuber, V., \& Lipowsky, F. (2016). Teacher self-efficacy as a long-term predictor of instructional quality in the classroom. European Journal of Psychology of Education, 31(3), 299-322. https://doi.org/ 10.1007/s10212-015-0272-7

Leithwood, K., \& Mascall, B. (2008). Collective leadership effects on student achievement. Educational Administration Quarterly, 44(4), 529-561. https://doi.org/10.1177/0013161X08321221

Leithwood, K., \& Jantzi, D. (1999). Transformational school leadership effects: A replication. School Effectiveness and School Improvement, 10(4), 451-479. https://doi.org/10.1076/sesi.10.4.451.3495

Li, L., \& Liu, Y. (2020). An integrated model of principal transformational leadership and teacher leadership that is related to teacher self-efficacy and student academic performance. Asia Pacific Journal of Education, 1-18. https://doi.org/10.1080/02188791.2020.1806036

Liu, J., Siu, O. L., \& Shi, K. (2010). Transformational leadership and employee well-being: The mediating role of trust in the leader and self-efficacy. Applied Psychology, 59(3), 454-479. https://doi.org/10.1111/ j.1464-0597.2009.00407.x

Lüdtke, O., Marsh, H. W., Robitzsch, A., \& Trautwein, U. (2011). A $2 \times 2$ taxonomy of multilevel latent contextual models: Accuracy-bias trade-offs in full and partial error correction models. Psychological Methods, 16(4), 444. https://doi.org/10.1037/a0024376.supp

Midgley, C., Feldlaufer, H., \& Eccles, J. S. (1989). Change in teacher efficacy and student self- and task-related beliefs in mathematics during the transition to junior high school. Journal of Educational Psychology, 81(2), 247-258. https://doi.org/10.1037/0022-0663.81.2.247

Mohorić, T., Smojver-Ažić, S., \& Močibob, M. (2020). Učestalost korištenja IKT-a kod nastavnika i učenika [Frequency of ICT use by teachers and students]. In S. Kolić-Vehovec (Ed.), Uvođenje suvremenih tehnologija u učenje i poučavanje: istraživanje učinaka pilot-projekta e-škole [Introduction of modern technologies in learning and teaching: Research of the effects of the e-schools pilot project] (pp. 63-92). Sveučilište u Rijeci, Filozofski fakultet. 
DRUŠ. ISTRAŽ. ZAGREB GOD. 30 (2021), BR. 2, STR. 181-202

BURIĆ I. ET AL: TRANSFORMATIONAL...
Muthén, L. K., \& Muthén, B. O. (1998-2017). Mplus user's guide. Seventh Edition. Muthén \& Muthén.

Nielsen, K., \& Munir, F. (2009). How do transformational leaders influence followers' affective well-being? Exploring the mediating role of self-efficacy. Work \& Stress, 23(4), 313-329. https://doi.org/10.1080/ 02678370903385106

Ninković, S. R., \& Knežević Florić, O. Č. (2018). Transformational school leadership and teacher self-efficacy as predictors of perceived collective teacher efficacy. Educational Management Administration \& Leadership, 46(1), 49-64. https://doi.org/10.1177/1741143216665842

Nir, A. E., \& Kranot, N. (2006). School principal's leadership style and teachers' self-efficacy. Planning and Changing, 37(3-4), 205-218.

Pahljina-Reinić, R., Rončević Zubković, B., \& Kolić-Vehovec, S. (2020). Digitalne kompetencije nastavnika i učenika [Digital competencies of teachers and students]. In S. Kolić-Vehovec (Ed.), Uvođenje suvremenih tehnologija u učenje i poučavanje: istraživanje učinaka pilot-projekta e-škole [Introduction of modern technologies in learning and teaching: Research of the effects of the e-schools pilot project] (pp. 119-142). Sveučilište u Rijeci, Filozofski fakultet.

Piccolo, R. F. \& Colquitt, J. A. (2006). Transformational leadership and job behaviors: The mediating role of core job characteristics. Academy of Management Journal, 49(2), 327-340. https://doi.org/10.5465/amj.2006. 20786079

Pillai, R., \& Williams, E. A. (2004). Transformational leadership, self-efficacy, group cohesiveness, commitment, and performance. Journal of Organizational Change Management, 17(2), 144-159. https://doi.org/ 10.1108/09534810410530584

Podsakoff, P. M., MacKenzie, S. B., Lee, J. Y., \& Podsakoff, N. P. (2003). Common method biases in behavioral research: A critical review of the literature and recommended remedies. Journal of Applied Psychology, 88(5), 879-903. https://doi.org/10.1037/0021-9010.88.5.879

Podsakoff, P. M., MacKenzie, S. B., Moorman, R. H., \& Fetter, R. (1990). Transformational leader behaviors and their effects on followers' trust in leader, satisfaction, and organizational citizenship behaviors. The Leadership Quarterly, 1(2), 107-142. https://doi.org/10.1016/1048-9843 (90)90009-7

Praetorius, A. K., Klieme, E., Herbert, B., \& Pinger, P. (2018). Generic dimensions of teaching quality: The German framework of three basic dimensions. ZDM, 50(3), 407-426. https://doi.org/10.1007/s11858-0180918-4

Redecker, C. (2017). European framework for the digital competence of educators: DigCompEdu (No. JRC107466). Joint Research Centre (Seville site).

Salanova, M., Lorente, L., Chambel, M. J., \& Martínez, I. M. (2011). Linking transformational leadership to nurses' extra-role performance: The mediating role of self-efficacy and work engagement. Journal of Advanced Nursing, 67(10), 2256-2266. https://doi.org/10.1111/j.1365-26 48.2011.05652.x 
DRUŠ. ISTRAŽ. ZAGREB GOD. 30 (2021), BR. 2, STR. 181-202

BURIĆ, I. ET AL.: TRANSFORMATIONAL..
Schiefele, U., \& Schaffner, E. (2015). Teacher interests, mastery goals, and self-efficacy as predictors of instructional practices and student motivation. Contemporary Educational Psychology, 42, 159-171. https://doi. org/10.1016/j.cedpsych.2015.06.005

Schwarzer, R., Schmitz, G. S., \& Daytner, G. T. (1999). The teacher self-efficacy scale. [On-line publication]. http://www.fu-berlin.de/gesund/ skalen/t_se.htm

Sun, J., \& Leithwood, K. (2012). Transformational school leadership effects on student achievement. Leadership and Policy in Schools, 11(4), 418-451. https://doi.org/10.1080/15700763.2012.681001

Thomas, L., Tuytens, M., Devos, G., Kelchtermans, G., \& Vanderlinde, R. (2018). Transformational school leadership as a key factor for teachers' job attitudes during their first year in the profession. Educational Management Administration and Leadership, 48(1), 106-132. https://doi.org/10.1177/1741143218781064

Thoonen, E. E., Sleegers, P. J., Oort, F. J., Peetsma, T. T., \& Geijsel, F. P. (2011). How to improve teaching practices: The role of teacher motivation, organizational factors, and leadership practices. Educational Administration Quarterly, 47(3), 496-536. https://doi.org/10.1177/00131 61X11400185

Tschannen-Moran, M., \& Woolfolk Hoy, A. (2001). Teacher efficacy: Capturing an elusive construct. Teaching and Teacher Education, 17(7), 783-805. https://doi.org/10.1016/S0742-051X(01)00036-1

Tschannen-Moran, M., Woolfolk Hoy, A., \& Hoy, W. K. (1998). Teacher efficacy: Its meaning and measure. Review of Educational Research, 68(2), 202-248. https://doi.org/10.3102/00346543068002202

Tschida, C., Hodge, E., \& Schmidt, S. (2016). Learning to teach online: Negotiating issues of platform, pedagogy and professional development. In V. Wang (Ed.), Handbook of research on learning outcomes and opportunities in the digital age (pp. 664-684). Information Science Reference. https://doi.org/10.4018/978-1-4666-9577-1.ch029

Valentine, J. W., \& Prater, M. (2011). Instructional, transformational, and managerial leadership and student achievement: High school principals make a difference. NASSP bulletin, 95(1), 5-30. https://doi. org/10.1177/0192636511404062

Voogt, J., Fisser, P., Pareja Roblin, N., Tondeur, J., \& van Braak, J. (2013). Technological pedagogical content knowledge - a review of the literature. Journal of Computer Assisted Learning, 29(2), 109-121. https://doi.org/ 10.1111/j.1365-2729.2012.00487.x

Yukl, G. (2013). Leadership in organizations (8th Edition). Upper Saddle River.

Zee, M., \& Koomen, H. M. (2016). Teacher self-efficacy and its effects on classroom processes, student academic adjustment, and teacher well-being: A synthesis of 40 years of research. Review of Educational Research, 86(4), 981-1015. https://doi.org/10.3102/0034654315626801 
DRUŠ. ISTRAŽ. ZAGREB

GOD. 30 (2021), BR. 2,

STR. 181-202

BURIĆ, I. ET AL.:

TRANSFORMATIONAL...
Transformacijsko vodstvo

i kvaliteta poučavanja tijekom pandemije COVID-19:

moderirana medijacijska analiza

Irena BURIĆ

Odjel za psihologiiju, Sveučilište u Zadru, Zadar, Hrvatska

Maja PARMAČ KOVAČIĆ, Aleksandra HUIĆ

Filozofski fakultet, Sveučilište u Zagrebu, Zagreb, Hrvatska

Zatvaranje škola uzrokovano pandemijom COVID-19 preko noći je primoralo nastavnike na poučavanje na daljinu, što je dovelo u pitanje njihovu radnu uspješnost. Transformacijsko (ruko)vođenje školom (TRŠ), samoefikasnost nastavnika (SEN) i njihove digitalne kompetencije možda su imale zaštitnu ulogu u takvim opterećujućim uvjetima. Cili ovog istraživanja bio je ispitati medijacijsku ulogu SEN-a u objašnjenju povezanosti TRŠ-a i kvalitete poučavanja. Dodatno, ispitana je i moderacijska uloga digitalnih kompetencija u objašnjenju povezanosti TRŠ-a i SEN-a, TRŠ-a i kvalitete poučavanja, kao i predloženoga medijacijskog mehanizma. Istraživanje, u kojem je sudjelovalo 1655 hrvatskih nastavnika, provedeno je online-upitnikom u proljeće 2020. godine. Medijacijske i moderirane medijacijske analize pokazale su da je TRŠ direktno i indirektno, preko SEN-a, pozitivno povezan s kvalitetom poučavanja. Digitalne kompetencije nastavnika nisu moderirale pretpostavljene veze ni medijacijski mehanizam.

Ključne riječi: transformacijsko (ruko)vođenje školom, radna uspješnost nastavnika, nastavnička samoefikasnost, digitalne kompetencije, moderirana medijacija

\section{cc) (1) \$}

Međunarodna licenca / International License:

Imenovanje-Nekomercijalno / Attribution-NonCommercial 